\title{
Selection of patients by dentists in a situation where health resources are scarce
}

\author{
Sérgio d'Ávila ${ }^{1}$, Alessandro Leite Cavalcanti ${ }^{1}$, Arnaldo de França Caldas JR ${ }^{2}$
}

\begin{abstract}
To identify which criteria influenced the selection of patients by dentists in a city of Northeastern Brazil. A cross-sectional study was carried out by collecting data through a questionnaire, consisting of identification data and a case scenario, 308 respondents had to choose, by looking at photos of six supposed patients, the only one who should receive emergency dental treatment in a situation of scarce health resources. The absolute and percent frequencies were obtained for data analysis (descriptive statistical techniques). For the selection of the six patients, the most frequently chosen patient was the 50 year old white male (70.5\%) followed by the female of African descent (12\%). The dentist's gender did not have a statistically significant effect on the choice of the patient $(\mathrm{P}=0.3366)$. Age was the most relevant criterion for the choice (46.4\%) followed by the patient's physiognomy (30.8\%). There was no significant difference between age and choice of the patient $(\mathrm{P}=0.8133)$. However, there was a significant association between age and reason of choice $(\mathrm{P}=0.0258)$. Subjective criteria interfered in the choice: the first impression caused by different physical features.
\end{abstract}

Key Words: allocation of resources, patient selection, health care rationing

\section{Selección de pacientes por dentistas en una situación en que los recursos de salud son escasos}

Resumen: Para identificar qué criterios influenciaron a los dentistas en la selección de pacientes en una ciudad del Nordeste de Brasil, se realizó un estudio transversal recolectando datos mediante un cuestionario, consistente en datos de identificación y un caso escenario. 308 Respondientes tuvieron que elegir, observando fotos de seis supuestos pacientes, el único que debería recibir tratamiento dental de emergencia en una situación de escasos recursos de atención de salud. Se obtuvo mediante el análisis de los datos las frecuencias absolutas y de porcentaje (técnicas estadísticas descriptivas). En la selección de los seis pacientes, el elegido más frecuentemente fue un hombre blanco de 50 años $(70,5 \%)$ seguido de una mujer de descendencia africana (12\%). El género del dentista no tuvo un efecto estadísticamente significativo en la elección del paciente $(\mathrm{P}=0,3366)$. La edad fue el criterio más relevante de elección (46,4\%) seguido de la fisionomía del paciente $(30,8 \%)$. No existió diferencia significativa entre la edad y la elección del paciente $(\mathrm{P}=0,8133)$. Sin embargo, existió una asociación significativa entre la edad y la razón de elección $(\mathrm{P}=0,0258)$. Criterios subjetivos interfirieron en la elección: la primera impresión causada por diferentes características físicas.

Palabras clave: distribución de recursos, selección de pacientes, racionamiento de atención de salud

\section{Seleção de pacientes por dentistas em situaçáo de escassos recursos sanitários}

Resumo: Para identificar qual critério influencia a seleção de pacientes por dentistas numa cidade do Nordeste do Brasil, um estudo de corte transversal foi realizado através de dados coletados por questionário, consistindo de dados de identificaçáo e o cenário de um caso. 308 respondentes fizeram a escolha pela observação de fotos de seis supostos pacientes, e somente um deveria receber o tratamento odontológico de emergência havendo recursos de saúde. As frequências absolutas e percentuais foram obtidas para análise de dados (técnicas de estatística descritiva). Na seleçáo dos seis pacientes, o paciente mais comumente escolhido foi do sexo masculino, 50 anos de idade, de cor branca (70,5\%), seguido por mulher de ascendência africana (12\%). O sexo do dentista não teve efeito estatisticamente significativo sobre a escolha do paciente $(\mathrm{P}=0,3366)$. A idade foi o critério mais relevante para a escolha $(46,4 \%)$, seguido da fisionomia do paciente $(30,8 \%)$. Não houve diferença significativa entre idade e escolha do paciente $(\mathrm{P}=0,8133)$. No entanto, houve uma associação significativa entre a idade e a razáo da escolha $(P=0,0258)$. Critérios subjetivos interferiram na escolha: a primeira impressão foi determinada pelas diferentes características físicas.

Palavras-chave: alocação de recursos, seleção de pacientes, critérios em cuidado de saúde

\footnotetext{
${ }^{1}$ Professor Public Health, Faculty of Dentistry, State University of Paraiba - UEPB, Campina Grande - PB, Brazi Correspondence: davila2407@hotmail.com

${ }^{2}$ Professor Public Health, Faculty of Dentistry, University of Federal of Pernambuco - UFPE, Recife - PE, Brazil
} 


\section{Introduction}

Ethics is the set of values, principles and standards used as the basis for human behavior; it guides us on what is right, correct and fair, as well as the responsibility of individuals for their actions, in order to live well in society(1). When it comes to everyday life, the emerging and exciting aspects give way to the more traditional and conservative ones, but that does not mean they are less important or not worthy of being analyzed(2). The decision making, integrating the main bioethical issues dignity, autonomy and responsibility — as unavoidable components in decisions geared to continuous total quality improvement in the vast field of medical care(3).

In order to make an ethical decision, as well as there being alternatives of action, an ethical person should be allowed to choose between possible options (freedom to choose) and have the freedom to act according to the choice made(1).

The process of decision making in situations where resources are lacking is never an easy task and can create many situations of contradictory positions, and conflict is inevitable. The ethical issues involved may make the process more complex, but provide, without doubt, an important reference to be used. What is important to remember is that the simplification of the process may make it less fair, while recognizing its complexity can guarantee this fundamental characteristic of ethical adequacy(4).

The criteria that are most commonly used for the allocation of resources are need, merit and effectiveness. The following are usually selected as social criteria: the patient's cooperation with health professionals, age, gender, workforce potentially affected and recovered, the life potential and expectancy and a supportive environment for follow-up treatment(5). However, the majority of decisions are taken in an implicit, intuitive fashion. There is evidence that health professionals do not share a common process of decision making.

In dentistry, there may also be such dilemmas between the point of view of the norm and the descriptive point of view when making a decision.
The task of the dentist when choosing the optimal treatment for each patient requires a rational assessment of the risks involved in a positive and negative decision. There is evidence that the characteristics of the patient, of the professional and of the work specifically influence the decisions made in treatment by dentists(6).

The process of solving a clinical problem is characterized by two elements of decision making: the first one is the content, a knowledge base that exists is in the memory of the professional who is looking for the solution of the problem; the second is the method of applying this knowledge in the attempt to resolve this existing problem(7).

There is very little Brazilian literature on studies that emphasize the decision to select who should receive dental care in a situation where resources are scarce. Thus, there is the need to develop research that could define what criteria may affect this decision. This research aims to identify which criteria influence the selection of patients by dentists in a city of northeastern Brazil, by considering age, race and gender. With this study we aim to improve the parameters of the patient-dentist relationship.

\section{Material and methods}

This cross-sectional study was carried out in the city of João Pessoa, Northwest, Brazil. For the study sample, 308 dentists were randomly selected from 1,555 professionals enrolled in the Council of Dentistry of the city.

This study used a standardized "case scenario", i.e. a case report. Case scenarios have been used in other trials and epidemiological research(5-7). Currently, they are being used in specific decisionmaking studies and are proving to be a method of great value. One of the advantages of this method is the ability to control variables and analyze to what extent they affect decision making(6).

The survey was sent to the Ethics and Research Committee of the State University of Paraiba (UEPB) along with a copy of the consent form in accordance with World Medical Association Declaration of Helsinki version 2002 guidelines and 
national health research norms.

The professionals were presented with a two-part questionnaire: the first part for data collection dealt with their identification, and the second presented the case scenario. The case was described as follows: At 17:45 six patients arrive at a Health Care unit that provides dental service on Fridays between 14 and 18 o'clock. None of them can afford to pay for private dental care. All patients have symptoms of pulpitis, but there is only one set of sterilized dental tools available. The case was presented and the following question asked: which patient should be treated?

Photographs of the patients were placed on the same page, identified by letters A to F to facilitate the definition of the sequence. The random sequence was as follows: picture A - a 30 year old female patient of African descent; picture $\mathrm{B}-\mathrm{a}$ 50 year old white male patient, photo $\mathrm{C}$ - a 30 year old male patient of African descent, picture $\mathrm{D}$ - a 20 year old white male patient; picture E a 30 year old white female patient, picture $\mathrm{F}-\mathrm{a}$ 30 year old white male patient. Patients who volunteered to give their images for the study were selected in the waiting rooms of University dental clinics and signed at the consent form. The selected patients wore a white shirt, so there would be standardization, and agreed to be photographed on a white wall, under the conditions set out in the consent form.

Data were collected using the technique of intensive direct observation in an individual interview carried out by the author, following a standardized or structured form.

For the data analysis, the study obtained absolute and percentual univariate and bivariate distribution variables in nominal scale measures statistics: minimum, maximum, mean, standard deviation and coefficient of variation for numerical variables (Descriptive statistical techniques) and were used Chi-square and Fisher exact tests. Data were entered in the Excel spreadsheet and the statistical software used to obtain the statistical calculations was SAS (Statistical Analysis System) version 8.0. The significance level used in the decisions of the statistical tests was $5.0 \%$.

\section{Results}

At the end of the study, a sample of 308 respondents' questionnaires were recorded and quantitatively analyzed. To identify the interviewee's social status (education and income) the following variables were used: age, sex and declared race.

Of the total respondents, $60.4 \%$ were women. Regarding race, $68.2 \%$ described themselves as white. $61,1 \%$ of respondents were married. Regarding the time elapsed since graduation, $46.1 \%$ graduated up to 10 years previously; $31.5 \%$ graduated over 21 years previously and $22.4 \%$ graduated between 31 and 40 years (table 1).

Table 1: Distribution of respondents according to the variables: race, marital status, time of graduation. João Pessoa - PB- Brazil, 2010

\begin{tabular}{|l|l|l|}
\hline & $n$ & $\%$ \\
\hline$\cdot$ race & & \\
\hline White & 210 & 68,2 \\
\hline No white & 98 & 31,8 \\
\hline TOTAL & 308 & 100,0 \\
\hline$\cdot$ Marital status & & \\
\hline Single & 95 & 30,9 \\
\hline Married & 188 & 61,1 \\
\hline Divorced & 25 & 8,1 \\
\hline TOTAL & 308 & 100,0 \\
\hline$\cdot$ Time of graduation (in years) & & \\
\hline Up to 10 & 142 & 46,1 \\
\hline 11 to 20 & 69 & 22,4 \\
\hline 21 or more & 97 & 31,5 \\
\hline TOTAL & 308 & 100,0 \\
\hline
\end{tabular}

Table 2 shows that the dentist's gender did not have a statistically significant effect on the choice of the patient $(\mathrm{P}=0.3366)$. The greatest difference occurred with patient $\mathrm{B}$, who was selected by $75.4 \%$ of females compared to $70.1 \%$ of males a $5.3 \%$ difference. 
Table 2: Distribution of respondents according to the variables: patient choice and relevant factor for the choice of the patient - João Pessoa - PBBrazil, 2010

\begin{tabular}{|l|l|l|}
\hline$\cdot$ Choice of patient & & \\
\hline A-30 year old female patient of African descent & 37 & 12.0 \\
\hline B- a 50 year old white male patient & 217 & 70.5 \\
\hline C- a 30 year old male patient of African descent & 8 & 2.6 \\
\hline D- a 20 year old white male patient & 16 & 5.2 \\
\hline E- a 30 year old white female patient & 15 & 4.9 \\
\hline F- a 30 year old white male patient & 3 & 1.0 \\
\hline Did not choose anybody & 12 & 3.9 \\
\hline TOTAL & 308 & 100.0 \\
\hline$\cdot$ Which factor was relevant for the choice & & \\
\hline Physiognomy & 95 & 30.8 \\
\hline Age & 143 & 46.4 \\
\hline Biological Factor & 49 & 15.9 \\
\hline Gender & 7 & 2.3 \\
\hline Necessity to work & 2 & 0.6 \\
\hline Would not treat anybody & 12 & 3.9 \\
\hline TOTAL & 308 & 100.0 \\
\hline
\end{tabular}

Table 3 shows the patient choice according to dentist's age group. This table highlights that the greatest percentage difference was recorded for the 31 to 40 years, with the choice of patient $\mathrm{B}$ (77.9\%). However, there was no significant difference between age and choice of the patient $(\mathrm{P}=0.8133)$.

Table 3: Assessment of the choice of patient according to the dentist's gender. Joáo Pessoa - PBBrazil, 2010

\begin{tabular}{|l|l|l|l|l|l|l|l|}
\hline $\begin{array}{l}\text { Choice } \\
\text { of } \\
\text { patient }\end{array}$ & Female & & Male & & $\begin{array}{l}\text { Group } \\
\text { total }\end{array}$ & $p$ Value \\
\hline & $n$ & $\%$ & $n$ & $\%$ & $n$ & $\%$ & \\
\hline A & 14 & 12.0 & 23 & 12.9 & 37 & 12.5 & $\begin{array}{l}p(1)= \\
0.3366\end{array}$ \\
\hline$B$ & 82 & 70.1 & 135 & 75.4 & 217 & 73.3 & \\
\hline C & 3 & 2.6 & 5 & 2.8 & 8 & 2.7 & \\
\hline$D$ & 8 & 6.8 & 8 & 4.5 & 16 & 5.4 & \\
\hline E & 7 & 6.0 & 8 & 4.5 & 15 & 5.1 & \\
\hline F & 3 & 2.6 & - & - & 3 & 1.0 & \\
\hline TOTAL & 117 & 100.0 & 179 & 100.0 & 296 & 100.0 & \\
\hline
\end{tabular}

(1) Using Fisher's Exact Test
As regards the dentist's race, the respondents did not present great percentage differences (table 4). The greatest difference was $2.3 \%$ for patient $\mathrm{C}$, greater among non-whites $(4.3 \%$ vs. $2.0 \%)$. Thus, no significant association was found between race and patient choice.

Table 4: Assessment of patient choice according to dentist's age group. João Pessoa - PB- Brazil, 2010

\begin{tabular}{|c|c|c|c|c|c|c|c|c|c|}
\hline \multirow{3}{*}{$\begin{array}{l}\text { Patient } \\
\text { Choice }\end{array}$} & \multicolumn{6}{|c|}{ Age Group (in years) } & & & \\
\hline & \multicolumn{2}{|c|}{22 to 30} & \multicolumn{2}{|c|}{31 to 40} & \multicolumn{2}{|c|}{41 or more } & \multicolumn{2}{|c|}{ Group total } & \multirow[t]{2}{*}{ p value } \\
\hline & $n$ & $\%$ & $n$ & $\%$ & $n$ & $\%$ & $n$ & $\%$ & \\
\hline$A$ & 11 & 10.8 & 9 & 10.5 & 17 & 15.7 & 37 & 12.5 & $p(1)=0.8133$ \\
\hline$B$ & 76 & 74.5 & 67 & 77.9 & 74 & 68.5 & 217 & 73.3 & \\
\hline C & 1 & 1.0 & 2 & 2.3 & 5 & 4.6 & 8 & 2.7 & \\
\hline$D$ & 6 & 5.9 & 4 & 4.6 & 6 & 5.6 & 16 & 5.4 & \\
\hline E & 7 & 6.9 & 3 & 3.5 & 5 & 4.6 & 15 & 5.1 & \\
\hline F & 1 & 1.0 & 1 & 1.2 & 1 & 0.9 & 3 & 1.0 & \\
\hline TOTAL & 102 & 100 & 86 & 100 & 108 & 100 & 296 & 100 & \\
\hline
\end{tabular}

(1) - Using the Likelihood-ratio test

No great difference was found regarding the gender and the reason for choice. The greatest difference was $6.4 \%$ for the patient's physiognomy which was highest among female dentists $(34.6 \%$ $\mathrm{x} 28.2 \%)$. The association between sex and reason for choice was not significant $(\mathrm{P}=0.8073)$ (table 5).

Table 5: Assessment of patient choice according to dentist's race. João Pessoa - PB- Brazil, 2010

\begin{tabular}{|c|c|c|c|c|c|c|c|}
\hline \multirow{3}{*}{ Patient choice } & \multicolumn{4}{|l|}{ Race } & & & \\
\hline & \multicolumn{2}{|c|}{ White } & \multicolumn{2}{|c|}{ Non-white } & \multicolumn{2}{|c|}{ Group total } & \multirow[t]{2}{*}{ p value } \\
\hline & $n$ & $\%$ & $n$ & $\%$ & $n$ & $\%$ & \\
\hline$A$ & 26 & 12.8 & 11 & 11.8 & 37 & 12.5 & $p(I)=0.8073$ \\
\hline$B$ & 148 & 72.9 & 69 & 74.2 & 217 & 73.3 & \\
\hline$C$ & 4 & 2.0 & 4 & 4.3 & 8 & 2.7 & \\
\hline$D$ & 11 & 5.4 & 5 & 5.4 & 16 & 5.4 & \\
\hline$E$ & 11 & 5.4 & 4 & 4.3 & 15 & 5.1 & \\
\hline$F$ & 3 & 1.5 & - & - & 3 & 1.0 & \\
\hline TOTAL & 203 & 100 & 93 & 100 & 296 & 100 & \\
\hline
\end{tabular}

(1) - Using Fisher's Exact test

Table 6 reveals that the percentage of those who chose the patient based on patient's age was higher among dentists aged 31 to 40 years $(57.0 \%)$ 
followed by those between 22 to 30 years old versus 31 to 40 years old regarding the patient's age ( $47.1 \%$ vs. $57.0 \%)$ and physiognomy $(35.3 \%$ vs. $25.6 \%)$. There was a significant association between age and reason of choice $(\mathrm{P}=0.0258)$. Furthermore, there was not a great percentage difference between whites and non-whites for the reason of choice. The greatest percentage difference occurred for the reason of gender, with the highest percentage difference occurring among non-whites and the association between race and choice was not significant.

Table 6: Assessment of reason for choice according to gender, age group and race of the dentist. João Pessoa - PB- Brazil, 2010

\begin{tabular}{|l|l|l|l|l|l|l|l|}
\hline & \multicolumn{4}{|l|}{ Gender } & \multicolumn{2}{l|}{} & \\
\hline Reason & \multicolumn{2}{|l|}{ Female } & \multicolumn{2}{l|}{ Male } & \multicolumn{2}{l|}{ Group total } & p value \\
\hline & $n$ & $\%$ & $n$ & $\%$ & $n$ & $\%$ & \\
\hline Physiognomy & 33 & 28.2 & 62 & 34.6 & 95 & 32.1 & $p(I)=0.2003$ \\
\hline Age & 56 & 47.9 & 87 & 48.6 & 143 & 48.3 & \\
\hline Biological factor & 24 & 20.5 & 25 & 14.0 & 49 & 16.6 & \\
\hline Gender & 2 & 1.7 & 5 & 2.8 & 7 & 2.4 & \\
\hline Necessity to work & 2 & 1.7 & - & - & 2 & 0.7 & \\
\hline TOTAL & 117 & 100 & 179 & 100 & 296 & 100 & \\
\hline
\end{tabular}

\begin{tabular}{|c|c|c|c|c|c|c|c|c|c|}
\hline \multirow{3}{*}{ Recason } & \multicolumn{6}{|c|}{ Aggegroutp (in yecars) } & & & \\
\hline & \multicolumn{2}{|c|}{2210030} & \multicolumn{2}{|c|}{315040} & \multicolumn{2}{|c|}{41 or more } & \multicolumn{2}{|c|}{ Group sootl } & p value \\
\hline & $n$ & $\%$ & $n$ & $\%$ & $n$ & $\%$ & $n$ & $\%$ & \\
\hline Physiggnomy & 36 & 35.3 & 22 & 25.6 & 37 & 34.3 & 95 & 32.1 & $p(2)=0.0258^{\circ}$ \\
\hline Age & 48 & 47.1 & ${ }_{49}$ & 57.0 & 46 & 42.6 & 143 & 48.3 & \\
\hline Biologial Factor & 12 & 11.8 & 14 & 16.3 & 23 & 21.3 & 49 & 16.6 & \\
\hline Gender & 6 & 5.9 & - & . & 1 & 0.9 & 7 & 2.4 & \\
\hline Necessity to work & & & 1 & 1.2 & I & 0.9 & 2 & 0.7 & \\
\hline TOTAL & 102 & 100 & 86 & 100 & 108 & 100 & 296 & 100 & \\
\hline
\end{tabular}

\begin{tabular}{|c|c|c|c|c|c|c|c|}
\hline \multirow{3}{*}{ Reason } & \multicolumn{4}{|l|}{ Race } & & & \\
\hline & \multicolumn{2}{|c|}{ White } & \multicolumn{2}{|c|}{ Non-white } & \multicolumn{2}{|c|}{ Group total } & p value \\
\hline & $n$ & $\%$ & $n$ & $\%$ & $n$ & $\%$ & \\
\hline Physiognomy & 65 & 32.0 & 30 & 32.3 & 95 & 32.1 & $p(3)=1.0000$ \\
\hline Age & 97 & 47.8 & 46 & 49.5 & 143 & 48.3 & \\
\hline Biological factor & 34 & 16.8 & 15 & 16.1 & 49 & 16.6 & \\
\hline Gender & 5 & 2.5 & 2 & 2.2 & 7 & 2.4 & \\
\hline Necessity to work & 2 & 1.0 & & & 2 & 0.7 & \\
\hline TOTAL & 203 & 100 & 93 & 100 & 296 & 100 & \\
\hline
\end{tabular}

(1) - Using Fisher's Exact test

$(*)$ - Significant association at $5.0 \%$ level

(2) - Using Likelihood-ratio test

(3) - Using Fisher's Exact test

\section{Discussion}

In dental literature, there is a scarcity of information using a case scenario that involves dilemmas over the allocation of scarce resources $(8,9)$. Regarding the use of criteria in the selection of people needing care and competing for health resources, there are divergences over the ethical validity of the criteria. Some claim that it is better to use them than to not use any criteria $(4,10-16)$ others think it is best to take random decisions $(14,16,18,19)$.

Based on the data collected, it can be seen that, in addition to the criteria such as age, gender and race, the physical appearance also influenced which potential candidate was chosen for the one vacancy for dental care.

The stereotypes are false or distorted ideas without foundation about individuals or groups, which can also cause prejudice. In professional practice, visual stereotypes and prejudice are a fundamental ethical issue since they mediate social relationships in this field (20).

It was found that $70.7 \%$ of respondents revealed interference due to first impressions, an attitude that is quite common in human relationships. In a study conducted in Australia(20) assessing what the choices and justifications of the population would be when having to choose between a newborn and a school-age child to receive a transplant, more than half of respondents (52\%) refused to choose, indicating that they would not consider the age difference as a criterion for decision making.

A study comparing the emergency care of a child who was less than seven years old and an elderly 65 year old, victims of a car accident. According to the survey data, the child was chosen by $72.7 \%$ of respondents, while $22.8 \%$ chose the elderly person. In the same survey in an emergency situation between two men, one aged 25 and the other 65 , also car accident victims, $60.8 \%$ chose the older patient and $36.2 \%$ chose the younger. This demonstrates that the results show a significant option for people who are in a disadvantageous situation(21).

Physicians can unintentionally incorporate racial 
stereotypes. They can also judge the patient, taking into account their ability to pay for an expensive treatment or the patient's desire for a given treatment(22-24).

These conceptions by professionals regarding the behavior and attitude of patients were confirmed by other authors(25). Through interviews, the cited authors found that doctors rated patients of African descent, after consultation, as being more likely to engage in high risk behavior and be less cooperative, regardless of their socioeconomic status.

In Brazil, previous study showed that dentists $s$ subjective criteria in the choice: the first impression caused by different physical appearances $(7$, 8).

In research by(26-31), comparing the conduct of invasive cardiac procedures in four groups: white males, white females, males of African descent and females of African descent, the authors concluded that more procedures were carried out on white males. Females and racial minorities received fewer cardiac procedures.

According to Giles et al.(26) and Giacomini(27), this fact could be due to differences in disease severity rather than the selection of patients. Moreover in the other research $(28,30-34)$ point out that females seek health care earlier than males, so their heart problems are less severe. This is a fact that may occur in Brazil since the Basic Health Care Units operate during business hours, 8:00 to $12: 00$ o'clock and 14:00 to $18: 00$ o'clock, which is the time when men are working, who consequently miss out on health care. There is no specific time to treat this economically active age group. In this study, the case reported is a common situation in health care units. People spend the day working and only seek care at the end of the working day to avoid missing work.
Dentists may also have preconceived ideas about patients, expressing their views on how these patients should be treated(35). In the analysis presented here, it was possible to diagnose, through questionnaires, racial influences, as shown in the following comments: "I do not like to discriminate against color or be accused of it. "The male of African descent has better preserved teeth because his enamel crystals are more resistant, as does the female of African descent." "Patients of African-descent apparently have a lower financial condition".

Public health policies need to be effective regarding the enforcement of the doctrinal principles of the System of Health in Brazil. These principles are: universality, comprehensiveness, and equity. Only then can one reflect upon who should be selected in situations where resources are scarce. In any event, our choices should be guided by ethics and avoid discrimination of people based on their race, gender, age or socioeconomic status. If selection criteria exist, they must be transparent, acknowledged and accepted by professionals and by society.

This is an undesirable situation, since there must be no discrimination against people due to their race, sex, age or socioeconomic status, in order to avoid that social criteria lead to discrimination of any kind.

\section{Conclusion}

Subjective criteria interfered in the choice: the first impression caused by different physical features. The selection criterion used was the patient's age. 


\section{References}

1. Callahan D, Jennings B. Ethics and Public Health: Forging a Strong Relationship. Am. J. public. Health 2002; 92(2): 169-176.

2. Rico JVM, Domínguez MO. Aspectos bioéticos en la toma de decisiones para la calidad de la atención en salud. Acta Bioethica 2010; 16(2): 142-147.

3. Joffe S, Manocchia M, Weeks JC, Cleary PD. What do patients value in their hospital care? An empirical perspective on autonomy centred bioethics. J. Med. Ethics. 2003; 29(2): 103-108.

4. Childress JF. Who shall live when not all can live? In: Edwards RB, Graber GC, editors. Bioethics. San Diego: Hacourt Brace Jovanovich Publishers; 1988: 745-755.

5. Busschbach JJV, Hessing DJ, Charro FT. The utility of health at different stages in life: a quantitative approach. Soc. Sci. Med. 1993; 37(2): 153-158.

6. Kay EJ, Blinkhorn ASA. Qualitative investigation of factors governing dentists treatment philosophies. Br. Dent. J. 1996; 180(5): 171-176.

7. Cabral ED, Caldas Jr AF, Cabral HAM. Influence of the patient's race on the dentist's decision to extract or retain a decayed tooth. Community Dent. Oral Epidemiol. 2005; 33(6): 461-466.

8. d'Avila S, Rago E, Maia AMA, Caldas-JR AF. Choice of patient: which the adopted approaches? Rev. Ciênc. Méd. PUCCAMP. 2006; 15(5): 399-406.

9. Athanassoulis N. Unusual Requests and the Doctor-Patient Relationship. The Journal of Value Inquiry 2006; 40(2-3): 259-278

10. Warren JJ, Hand JS, Levy SM, Kirchner HL. Factors related to decision to extract or retain at-risk teeth. J. Public. Health Dent. 2000; 60(1): 39-42.

11. Mathews SC, Pronovost PJ. Physician Autonomy and Informed Decision Making: Finding the Balance for Patient Safety and Quality. JAMA 2008; 300(24): 2913-2915.

12. Kilner JF. Microallocation. In: Reich WT. (editor) Encyclopedia of bioethics. New York: Macmillan Library Reference; 1995: 1075-1084.

13. Buchanan A. Health-care delivery and resource allocation. In: Veatch RM. (org.) Medical ethics. Boston: Jones and Bartlett Publishers; 1989: 291-327.

14. Starfield B. Improving equity in health: a research agenda. Int. J. Health Serv. 2001; 31(3): 545566.

15. Staudenmayer H, Lefkowitz MS. Physician-patient psychosocial characteristics influencing medical decision-making. Soc. Sci. Med. 1981; 15(1): 77-81.

16. Mackinlan JB, Potter DA, Feldman HA. Non-medical influences on medical decision-making. Soc. Sci. Med. 1996; 42(5): 769-776.

17. Childress JF. Ethics and the allocation of organs for transplantation. Kennedy Inst. of Ethics J. 1996; 6(4): 397-401.

18. Fortes PAC. Select you must live: a study on bioethics micro allocation criteria for social resources in medical emergencies. Rev. Assoc. Med. Bras. 2000; 48(2): 129-134.

19. Sheu S-J, Huang S-H, Tang F-I, Huang S-L. Ethical decision making on truth telling in terminal cancer: medical students choices between patient autonomy and family paternalism. Med. Educ. 2006; 40(6): 590-598.

20. Nord E, Richardson J, Street A, Kuhse H, Singer P. Maximizing health benefits vs egalitarianism: an australian survey of health issues. Soc. Sci. Med. 1995; 41(10): 1429-1437.

21. Fortes PAC, Zoboli ELCV, Spinetti, SR. Social criteria for selecting patients in emergency services. Journal of Public Health 2001; 35(5): 451-455.

22. Kahn KL, Pearson ML, Harrison ER, Desmond KA, Rogers WH, Rubenstein LV, et al. Health care for black and poor hospitalized medicare patients. JAMA 1994; 271(15): 1207-1208.

23. O'Malley MS, Earp JAL, Harris RP. Race and mammography use in two North Carolina Counties. Am. J. Public Health 1997; 87(5): 782-786.

24. Cooper-Patrick L, Gallo JJ, Gonzales JJ, Vu HT, Powe NR, Nelson C, et al. Race, gender and partnership in the patient-psysician relatioship. JAMA 1999; 282(6): 583-589. 
25. Ryn M, Burke J. The effect of patient race and socio-economic status on physicians perceptions of patients. Soc. Sci. Med. 2000; 50(6): 813-828.

26. Giles WH, Anda RF, Casper ML, Escobedo LG, Taylor HA. Race and Sex differences in rates of invasive cardiac procedures in US hospitals. Arch. Intern. Med. 1995; 155(8): 318-324.

27. Giacomini MK. Gender and ethnic differences in Hospital-based procedure utilization in California. Arch. Intern. Med. 1996; 156(10): 1217-1224.

28. Seils DM, Friedman JY, Schulman KA. Sex differences in the referral process for invasive cardiac procedures. J Am Med Womens Assoc. 2001; 56(4): 151-154.

29. Lucas FL, De Lorenzo MA. Siewers AE. Wennberg DE. Temporal Trends in the Utilization of Diagnostic Testing and Treatments for Cardiovascular Disease in the United States, 1993-2001. Circulation 2006; 113(3): 374-379.

30. Coffey RM, Andrews RM, Moy E. Racial, ethnic, and socioeconomic disparities in estimates of AHRQ patient safety indicators. Med.Care. 2005; 43(3): 48-57.

31. Alexander GC, Sehgal AR. Barriers to cadaveric renal transplatation among blacks, women, and the poor. JAMA 1998; 280(13): 1148-1152.

32. Johnson RL, Roter D, Powe NR, Cooper AL. Patient race/ethnicity and quality of patient-physician communication during medical visits. Am. J. Public Health. 2004; 94(12): 2084-2090.

33. Schulman KA, Berlin JA, Harless W, Kerner JF, Sistrunk S, Gersh BJ. The effect of race and sex on psysicians recommendations for cardiac catheterization. N. Engl. J. Med. 1999; 340(8): 618-626.

34. Bertoni AG, Bonds DE, Lovato J, Goff DC, Brancati FL. Sex disparities in procedure use for acute myocardial infarction in the United States, 1995 to 2001. Am. Heart J. 2004; 147(6): 1054-1060.

35. Tickle M, Milson K, Blinkhorn A. Inequalities in the dental treatment provided to children: an example from the UK. Community Dent. Oral Epidemiol. 2002; 30(5): 335-341.

Recibido: 26 de agosto de 2011

Aceptado: 10 de octubre de 2011 